\title{
IDENTIFIKASI SENYAWA METABOLIT SEKUNDER DAUN PETAI CINA (Leucaena leucocephala (Lamk.) De Wit) DAN UJI AKTIVITAS ANTIBAKTERI Staphylococcus aureus ${ }^{1}$ Ermi Abriyani, S.Si., M.Si, ${ }^{2}$ Neneng Nurfalah \\ ${ }^{1}$ Prodi Farmasi Fakultas Teknologi dan Ilmu Komputer Universitas Buana Perjuangan Karawang (ermiabriyani@ubpkarawang.ac.id,) \\ ${ }^{2}$ Prodi Farmasi Fakultas Teknologi dan Ilmu Komputer Universitas Buana Perjuangan Karawang (fm15.nenengnurfalah@mhs.ubpkarawang.ac.id)
}

\begin{abstract}
ABSTRAK
Salah satu tumbuhan yang digunakan sebagai obat tradisional adalah petai cina (Leucaena leucocephala (Lamk.) de Wit). Secara etnobotani, masyarakat Indonesia telah memanfaatkan daun petai cina sebagai obat-obatan diantaranya sebagai obat luka dan obat bengkak. Petai cina diketahui potensial untuk dikembangkan lebih lanjut pada penyakit infeksi. Berdasarkan hal ini dilakukan penelitian mengenai identifikasi metabolit sekunder daun petai cina. Metode yang digunakan yaitu soxhlet, uji fitokimia, ekstraksi cair-cair, kromatografi kolom, uji antibakteri mengunakan metode difusi paper disk dengan konsentrasi $10 \% \mathrm{~b} / \mathrm{v}, 20 \% \mathrm{~b} / \mathrm{v}, 30 \%$ $\mathrm{b} / \mathrm{v}, 40 \% \mathrm{~b} / \mathrm{v}, 50 \%$. b/v. Pada pengujian karakteristik senyawa metabolit sekunder daun petai cina memiliki potensi yaitu senyawa alkaloid, flavonoid, tanin, polifenol dan steroid. Pada pengujian antibakteri menunjukkan konsentrasi $50 \%$ zona hambat paling besar dengan hasil pengukuran $6,16 \mathrm{~mm}$ pada ekstrak etanol dan pada ekstak n- heksana 4,44 mm.
\end{abstract}

Kata Kunci: $\quad$ Daun Petai Cina (Leucaena leucocephala (Lamk.) de Wit)), Ekstraksi cair-cair, Kromatografi lapis tipis, Kromatografi kolom, St

\begin{abstract}
ABSTRACK
One of the plants used as traditional medicine is (Leucaena leucocephala (Lamk.) De Wit). Ethnobotany, Indonesian people have used Chinese petai leaves as medicines, including wound medicine and swollen medicine. Chinese petai is known to be potential for further development in infectious diseases. Based on this, a study was conducted on the identification of secondary metabolites of Chinese petai leaves. The method used is soxhlet, phytochemical test, liquid-liquid extraction, column chromatography, antibacterial test using paper disk diffusion method with a concentration of $10 \% \mathrm{~b} / v, 20 \% \mathrm{~b} / \mathrm{v}, 30 \% \mathrm{~b} / \mathrm{v}, 40 \% \mathrm{~b} / \mathrm{v}, 50 \% . \mathrm{b}$ $/ v$. In testing the characteristics of secondary metabolites of Chinese petai leaves, they have the potential of alkaloid compounds, flavonoids, tannins, polyphenols and steroids. The antibacterial test for a concentration of 50\% has the largest inhibition zone with results of measurements of $6.16 \mathrm{~mm}$ on ethanol extract and on n-hexane extract $4.44 \mathrm{~mm}$.
\end{abstract}

Keywords: (Leucaena leucocephala (Lamk.) De Wit)), Liquid- liquid Extraction Cromatography column, Thin Layer Cromatography, Staphylococcus aureus 


\section{PENDAHULUAN}

Seiring dengan kemajuan teknologi dan kehidupan masyarakat yang ingin serba cepat dan praktis, pola makanan pun ikut bergeser. Sarapan dengan sereal instan merupakan salah satu pilihan yang mulai populer dan digemari oleh masyarakat Indonesia (Dewanti,T, 2012). Penggunaan bahan alam kini semakin meningkat, terlebih lagi dengan adanya isu back to nature, serta krisis keuangan menyebabkan menurunnya daya beli masyarakat. Salah satu obat tradisional yang saat ini berpotensi untuk dikembangkan adalah tanaman petai cina (Leucaena leucocephala). Tanaman petai cina merupakan salah satu tanaman tropis yang kelimpahannya cukup besar di kabupaten Karawang, Indonesia. Tanaman ini mempunyai potensi senyawa bioaktif yang dapat dimanfaatkan sebagai obatobatan herbal. Masyarakat telah memakai daun dari tanaman petai cina sebagai obat luka dan obat bengkak (Praja, M.H., dan Oktarina, R.Z., 2016).

Dari penelitian yang sudah dilakukan menurut Sartinah (2010) ekstrak daun petai cina menunjukkan aktivitas antibakteri terhadap bakteri Staphylococcus aureus. Menurut Togubu (2013) Daun petai cina dapat menurunkan kadar glukosa darah karena memiliki senyawa aktif yaitu flavonoid, saponin, alkaloid, dan tanin. Beberapa penelitian menyebutkan bahwa daun petai cina mengandung zat aktif alkaloid, saponin, flavonoid, lektin dan tanin. (Rahmawati, 2014). Berdasarkan hal diatas maka dilakukanlah penelitian dengan mengidentifikasi senyawa- senyawa metabolit sekunder dan uji aktivitas antibakteri terhadap bakteri Staphylococcus aureus.

\section{METODE PENELITIAN}

\section{Peralatan yang digunakan dalam penelitian}

Peralatan yang digunakan adalah peralatan gelas yang umum dipakai penelitian kimia organik bahan alam, satu set alat soxhlet, seperangkat alat destilasi pelarut, rotary evaporator, oven, memmert basic water bath-WNB 14, LAF, neraca analitik, autoklaf, lampu UV model UV GL 58 UV 245 dan 366 nm, plat KLT (silika gel G 60 F254), kolom, inkubator, jarum ose, kertas saring, silika, pipet tetes, pipa kapiler, paper disk, DMSO, Ciprofloxsasin, 


\section{Bahan yang digunakan dalam penelitian}

Sampel yang digunakan adalah daun petai cina yang dikumpulkan dari area pemukiman Karawang Timur, Jawa Barat.

Bahan lain yang digunakan adalah n-heksana, etil asetat, etanol, metanol, aquadest, serbuk magnesium, silika gel, kertas whatcman, kapas steril, ciprofloxacin, DMSO (Dimetil sulfoksida), bakteri Staphylococcus aureus, plat KLT (silika gel G 60 F254), pipa kapiler, aluminium foil, dan kertas saring. Pereaksi mayer untuk identifikasi alkaloid, pereaksi lieberman burchard untuk identifikasi terpenoid dan steroid, sianidin tes untuk identifikasi flavonoid, dan $\mathrm{FeCl}_{3}$ untuk identifikasi fenolik dan tanin.

Penelitian ini menggunakan metode soxhlet, ekstraksi cair-cair, fraksinasi dengan kromatografi kolom, uji antibakteri menggunakan metode paper disk.

\section{PEMBAHASAN}

Determinasi tumbuhan dimaksudkan untuk mendapatkan jenis tumbuhan yang digunakan dengan jelas. Tanaman daun petai cina ini dideterminasi di Laboratorium Institut Teknologi Bandung Fakultas Sekolah Ilmu dan Teknologi Hayati. Determinasi dilakukan dengan mencocokkan tanaman No. 407/D/KM/2018 dengan ciri- ciri morfologi tumbuhan petai cina yang digunakan penelitian dengan acuan pustaka. Hasil determinasi menunjukkan bahwa tanaman yang digunakan dalam penelitian ini adalah Leucaena leucocephala (Lamk.) de Wit.

Ekstrak yang dihasilkan dari 300 gram serbuk petai cina dengan soxhlet menggunakan pelarut etanol adalah 27,3 gram, 61,72 gram, 13,71 gram. Didapatkan hasil ekstraksi cair cair menggunakan pelarut n-heksana yaitu 22,81 gram, 20,17 gram, 53,95 gram. 


\section{Uji Fitokimia}

Berdasarkan dari uji fitokimia ekstrak daun petai cina, didapatkan sebaga berikut:

Tabel 1. Hasil Uji Fitokimia

\begin{tabular}{ccccc}
\hline No. & $\begin{array}{c}\text { Kandungan } \\
\text { Kimia }\end{array}$ & Pereaksi & Hasil & Keterangan \\
\hline 1. & Flavonoid & Sianidin test & + & Orange kemerahan \\
2. & Saponin & $\mathrm{H}_{2} \mathrm{O}$ & - & Tidak terdapat busa \\
3. & Tanin & $\mathrm{FeCl}$ & + & Warna hijau \\
4. & Polifenol & $\mathrm{FeCl}$ & + & Hitam pekat \\
5. & Steroid & Lieberman & + & Warna Hijau \\
& Burchard & + & \\
6. & Terpenoid & Lieberman & - & Kuning jernih \\
7. & Alkaloid & Dragendord & + & ada endapan jingga \\
\hline
\end{tabular}

Keterangan : (+) Ada, Tidak ada (-)

\section{Fraksinasi dengan kolom}

Ekstrak kental etanol dilakukan fraksinasi untuk memisahkan senyawa komponen yang ada pada ekstrak daun petai cina menggunakan kromatografi kolom dengan absorben silika gel G 60 F254 sebagai fasa diam dan eluen n-heksana : etil asetat, etil asetat : metanol sebagai fasa gerak yang kepolarannya terus ditingkatkan. Hasil fraksinasi didapatkan 17 fraksinasi dalam 145 vial . Didapatkan noda yang sama dengan menggabungkan tiap vial kedalam satu fraksi lalu diuapkan pelarutnya.

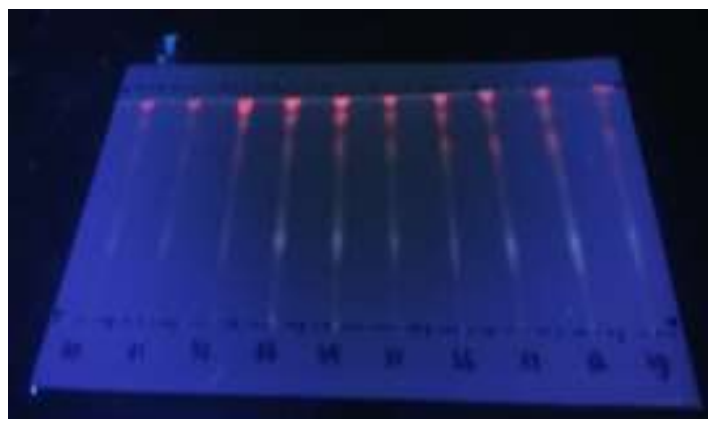

Gambar 1. Hasil Fraksinasi dengan Kolom

Berdasarkan gambar 1 dilakukan elusi dengan perbandingan 5:5 (etil asetat: etanol) dilihat dibawah lampu UV $254 \mathrm{~nm}$ didapat hasil $\operatorname{Rf} 0,33$ pada vial 30- 39 menunjukkan warna floresensi, Pada lampu UV $366 \mathrm{~nm}$ menunjukkan warna kuning muda. 
Dilakukan pengujian dengan sedikit mengambil ekstrak didalam vial (fraksi 1) dan diuji dengan pereagen fitokimia, tujuannya memperkirakan hasil yang didapat dalam suatu metabolit sekunder. Dilakukan dengan penambahan $\mathrm{FeCl}_{3} \quad 5 \%$ menunjukkan warna orange yang termasuk kedalam polifenol.

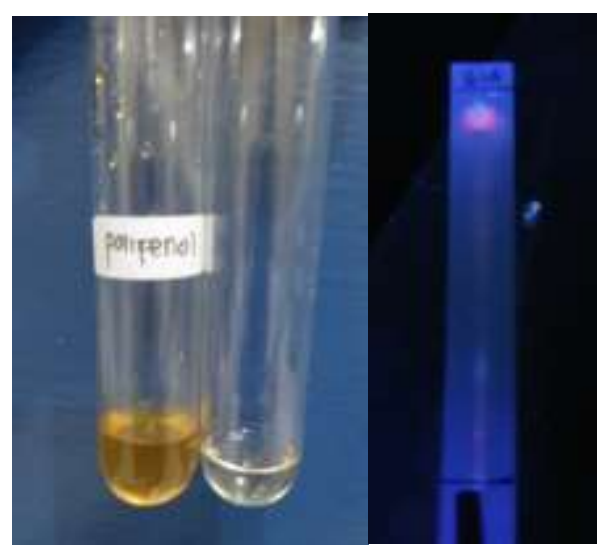

Gambar 2 Hasil uji fitokimia dan KLT (fraksi 1)

Lalu dilakukan elusi pada fraksi 1 dengan perbandingan 6:4 dapat dilihat pada Gambar 2 Didapatkan hasil Rf 0,25 dengan menunjukkan warna floresensi dlihat pada lampu UV $254 \mathrm{~nm}$. Sedangkan pada lampu UV $366 \mathrm{~nm}$ menunjukkan sedikit warna kuning. Menurut Achmad (1996) jika senyawa yang diuji dengan KLT memberikan noda tunggal maka hasil isolasi sudah murni. Dapat diketahui bahwa ekstrak daun petai cina masih mengandung berbagai komponen senyawa (belum murni), hal ini dibuktikan dengan hasil KLT yang masih mengandung banyak noda.

\section{Uji Antibakteri Staphylococcus aureus}

Uji aktivitas antibakteri dengan metode difusi dilakukan replikasi sebanyak 3 kali pada tiap konsentrasi uji dan kontrol uji. Pengujian antibakteri dengan menggunakan medium utrient Agar (NA). Digunakan kontrol positif ciprofloxacin dan kontrol negatif DMSO dengan konsentrasi 10\%, 20\%, 30\%, 40\%, 50\%. Berdasarkan hasil penelitian menunjukkan bahwa ekstrak etanol daun petai cina menghasilkan diameter zona hambat kategori lemah hingga sedang. Pada ekstrak n- heksana menghasilkan diameter zona hambat kategori lemah disebabkan memiliki aktivitas antibakteri yang rendah terhadap kandungan senyawa aktif sehingga senyawa pada ekstrak n- heksan yang tertarik sedikit. Ekstrak etanol 
memiliki zona hambat paling luas dikarenakan komponen-komponen yang dapat diekstrak oleh pelarut etanol dapat menarik senyawa polar dan non-polar, sedangkan n-heksan hanya dapat menarik senyawa non-polar. Oleh sebab itu, etanol dapat mengekstrak lebih banyak senyawa dibandingkan pelarut n-heksan. Hal ini juga telah dibuktikan pada uji fitokimia senyawa aktif dalam daun petai cina menunjukan bahwa ekstrak etanol memiliki kandungan senyawa aktif lebih banyak di bandingkan dengan ekstrak n-heksan. Menurut Susanto, Sudrajat dan Ruga, 2012, kriteria kekuatan antibakteri yaitu $0-5 \mathrm{~mm}$ rendah jika diameter zona hambat $5 \mathrm{~mm}$ atau kurang maka aktivitas penghambatan dikategorikan lemah, diameter zona hambat sebesar 6-10 mm maka dikatagorikan sedang, diameter zona hambat sebesar 11-20 mm maka dikatagorikan kuat dan jika diameter zona hambat $21 \mathrm{~mm}$ atau lebih maka aktivitas penghambatan dikatagorikan sangat kuat.

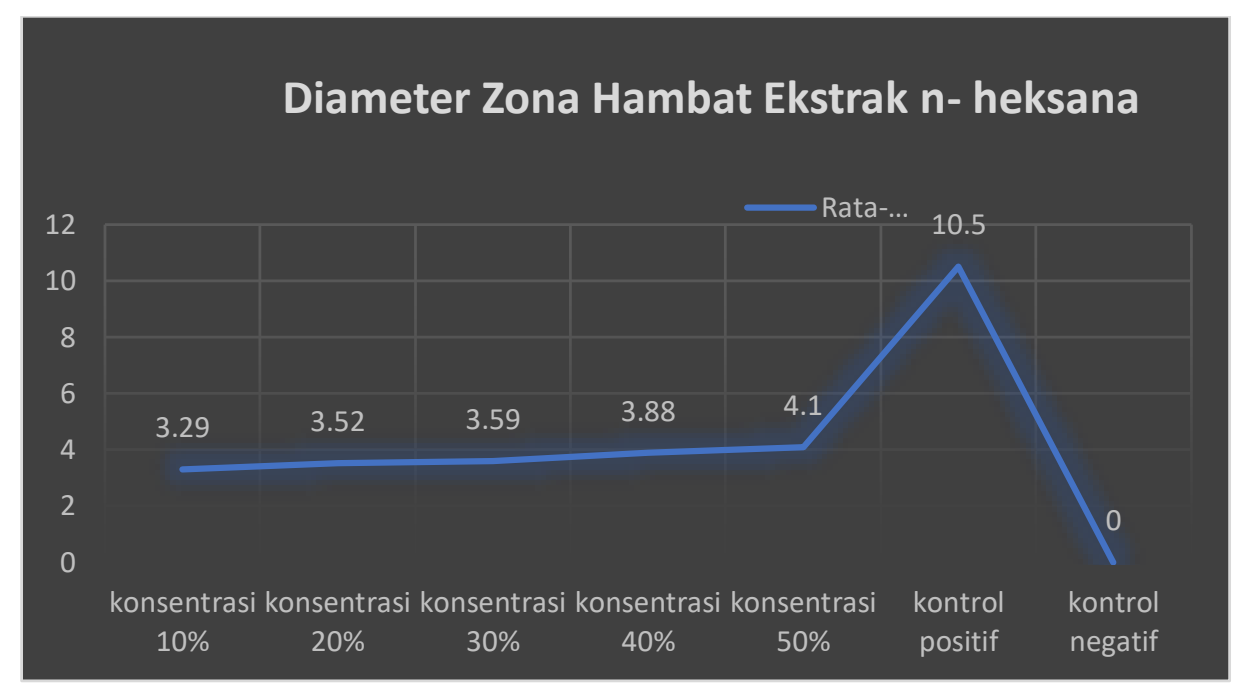

\section{Gambar 3. Diameter Zona Hambat Ekstrak n-heksana}

Pemilihan pelarut etanol $96 \%$ dan n-heksan adalah karena pada penelitian ini di harapkan mendapatkan zat aktif yang terlarut dalam pelarut polar dan non polar, sehingga dapat menjadi acuan untuk mengetahui zat aktif yang di peroleh dari daun peta cina. Staphylococcus aureus merupakan gram positif yang sensitif terhadap antibiotik ciprofloxacin. Hal ini menunjukan bahwa ekstrak daun petai cina mengandung zat antibakteri yang dapat menghambat pertumbuhan bakteri walaupun daya hambatnya dalam rentang lemah sampai sedang. Kemampuan ekstrak daun petai cina dalam menghambat pertumbuhan bakteri Staphylococcus 
aureus karena adanya beberapa kandungan senyawa metabolit pada daun petai cina yaitu senyawa flavonoid, tanin, polifenol, alkaloid, steroid yang dapat memiliki aktivitas antibakteri. Fenol dapat bersifat desinfektan yang bekerja dengan cara mendenaturasi protein yanag dapat menyebabkan aktifitas metabolisme ini akan mengakibatkan kematian sel bakteri (Miranti, 2013). Flavonoid yaitu dengan menyebabkan kerusakan permeabilitas dinding bakkteri dan mengahambat motilitas bakteri (Darsana, 2012). Tanin juga menyerang polipeptida dinding sel sehingga menyebabkan kerusakan dinding sel pada bakteri (Ji Ys, 2012). Steroid sebagai antibakteri berhubungan dengan membran lipid dan sensitivitas terhadap komponen steroid yang menyebabkan kebocoran pada liposom menyebabkan integritas membran menurn seta morfologi membran sel berubah yang menyebabkan sel rapuh dan lisis (Ji Ys, 2012).

\section{PENUTUP}

\section{Kesimpulan}

Berdasarkan hasil penelitian yang dilakukan dapat disimpulkan sebagai berikut:

1. Daun petai cina mengandung senyawa flavonoid, tanin, polifenol, steroid dan alkaloid.

2. Daun petai cina memiliki aktivitas antibakteri terhadap bakteri Staphylococcus aureus dengan konsentrasi 10\%, 20\%, 30\%, 40\%, 50\% . Pada pengujian antibakteri menunjukkan konsentrasi $50 \%$ zona hambat paling besar dengan hasil pengukuran $6,16 \mathrm{~mm}$ pada ekstrak etanol dan pada ekstak n- heksana 4,44 $\mathrm{mm}$. 


\section{DAFTAR PUSTAKA}

Ahmad, H. (1996). Penuntun Belajar Kimia Dasar: Kimia Larutan. Bandung: PT Citra Aditya Bakti

Darsana, I. G. O. (2012). Potensi Daun Binahong (Anredera Cordifolia (Tenore) Steenis) dalam Menghambat Pertumbuhan Bakteri Escherichia Coli secara In Vitro. Indonesia Medicus Veterinus, 1(3), 337 -351

Dewanti, Tri. Dkk. 2012. Tepung Bubur Sereal Instan Metode Ekstruksi dari Sorgum dan Kecambah Kacang Tunggak (Kajian Proporsi Bahan dan Penambahan Maltodekstrin). Jurnal Teknologi Pertanian Vol. 3 No.1 : 35-44. Universitas Brawijaya

Miranti, S, T. Pembuatan Karbon Aktif Dari Bambu Dengan Metode Aktivasi Terkontrol Menggunakan Aktivating Agent H3PO4 dan KOH. Jurusan Teknik Universitas Indonesia, Departemen Teknik Kimia, Universitas Indonesia. 2012

Praja, M.H. dan Oktarina, R. Z., 2016, Uji Efektivitas Daun Petai Cina (Laucaena glauca) Sebagai Antiinflamasi Dalam Pengobatan Luka Bengkak ., Majority, Volume 5, Nomor 5.

Rahmawati, I. 2014. Perbedaan Efek Perawatan Luka Menggunakan Gerusan Daun Petai Cina (Leucaena glauca, Benth) Dan Povidon Iodine 10\% Dalam Mempercepat Penyembuhan Luka Bersih Pada Marmut (Cavia porcellus). Jurnal Wiyata 1 (2).

Sartinah A., 2010. Isolasi Dan Identifikasi Senyawa Antibakteri Dari Daun Petai Cina. Fakultas Farmasi Universitas Gadjah Mada, Majalah Obat Tradisional, 15 (3), 146 - 152, 2010, Yogyakarta.

Susanto, Sudrajat D, Ruga R. 2012. Studi kandungan bahan aktif tumbuhan meranti merah (Shorea leprosula Miq) sebagai sumber senyawa antibakteri . Mulawarman scientific. (2):181-90 